\title{
The distribution of 4-nonylphenol in marine organisms of North American Pacific Coast estuaries
}

\author{
Jennifer Diehl , Sarah E. Johnson , Kang Xia , Amy West , Lars Tomanek
}

\begin{abstract}
A B S T R A C T
One of the chemical breakdown products of nonylphenol ethoxylates, 4-nonylphenol (4-NP), accumulates in organisms and is of concern as an environmental pollutant due to its endocrine disrupting effects. We measured 4-NP levels in the seawater, sediment, and twelve organisms within the California estuary, Morro Bay, and examined biomagnification of 4-NP using stable isotope abundances $\left(\delta^{15} \mathrm{~N}\right.$ and $\left.\delta^{13} \mathrm{C}\right)$ to quantify trophic position. 4-NP concentrations in organisms from Morro Bay included $25000 \pm 8600 \mathrm{ng} \mathrm{g}^{-1} \mathrm{lw}$ in liver of California sea lion, $14000 \pm 5600 \mathrm{ng} \mathrm{g}^{-1} \mathrm{lw}$ in liver of harbor porpoise, $138000 \pm 55000 \mathrm{ng} \mathrm{g}^{-1} \mathrm{lw}$ in liver of sea otters, $15700 \pm 3600 \mathrm{ng} \mathrm{g}^{-1}$ lw in liver of seabirds, $36100 \pm 6100 \mathrm{ng} \mathrm{g}^{-1}$ lw in arrow goby fish, $62800 \pm 28400 \mathrm{ng} \mathrm{g}^{-1} \mathrm{lw}$ in oysters, and $12700 \pm 1300 \mathrm{ng} \mathrm{g}^{-1} \mathrm{lw}$ in mussels. 4-NP levels generally showed a pattern of trophic dilution among organisms in Morro Bay, with exceptions of biomagnification observed between three trophic links: mussel to sea otter (BMF 10.9), oyster to sea otter (BMF 2.2), and arrow goby to staghorn sculpin (BMF 2.7). Our examination of other west coast estuaries of USA and Canada revealed that mean 4-NP concentrations in gobies and mussels from Morro Bay were significantly higher than those from a more urbanized estuary, San Francisco Bay (goby: $11100 \pm 3800 \mathrm{ng} \mathrm{g}^{-1} \mathrm{lw}$ ) and from a remote estuary, Bamfield Inlet, Canada (goby: $9000 \pm 900 \mathrm{ng} \mathrm{g}^{-1} \mathrm{lw}$, mussel: $6100 \pm 700 \mathrm{ng} \mathrm{g}^{-1} \mathrm{lw}$ ). Relative to other estuaries worldwide, 4-NP levels in seawater $\left(0.42 \pm 0.16 \mu \mathrm{g} \mathrm{L}^{-1}\right)$ and sediment $(53 \pm 14$ $n g \mathrm{~g}^{-1} \mathrm{dw}$ ) of Morro Bay are low, but gobies and oysters have higher 4-NP levels than comparable fauna.
\end{abstract}

\section{Introduction}

Nonylphenol ethoxylates are anthropogenically-produced substances utilized as stabilizers in plastics, as surfactants in detergents, agricultural sprays, and personal care products, and as spermicide in contraceptives. In 2000, approximately 128 million $\mathrm{kg}$ of nonylphenol were produced in the United States (Chemical Market Reporter, 2001). Although the long-chained, relatively water-soluble ethoxylates degrade during the wastewater treatment process, one of the breakdown products 4-nonylphenol (4-NP) is hydrophobic, adheres easily to sediment rich in organic material, concentrates in tissues with high lipid content, and can persist for decades in anaerobic environments, such as the mudflats of estuaries (Ying et al., 2002; Soares et al., 2008).

Environmental contamination by 4-NP is of concern because 4NP acts as a xenoestrogen (Rempel and Schlenk, 2008) disrupting endocrine signaling to a higher degree than expected based on its relative affinity for estrogen receptors (Soto et al., 1991;
Acevedo et al., 2005). 4-NP exposure has been demonstrated to have consequences for several vertebrate taxa, and in fish has been observed to induce production of the egg-yolk protein vitellogenin in males, modify testicular structure and decrease sperm counts, lead to both intersex fish and altered sex ratios in populations, and induce both liver damage and mortality (96 h LC50 values: 17-3000 $\mathrm{g} \mathrm{L}^{-1}$ ) (Servos, 1999; Staples et al., 2004; Vazquez-Duhalt et al., 2005). When exposed to 4-NP, marine invertebrates exhibit biological impairments, including impaired larval development, decreased growth rates, growth abnormalities, and reduced survival (96 h LC50 values: 20.7-3000 $\mu \mathrm{g} \mathrm{L}^{-1}$ ) (Servos, 1999; Staples et al., 2004; Vazquez-Duhalt et al., 2005).

Due to the high $K_{\text {ow }}$ of 4-NP, more 4-NP adsorbs to sediment than persists in seawater, and aquatic organisms that ingest sediment may be particularly vulnerable to 4-NP accumulation (David et al., 2009). Bioaccumulation of 4-NP has been demonstrated in aquatic organisms in both field- and laboratory-based exposure studies (Liber et al., 1999; Correa-Reyes et al., 2007). To date, however, few studies have investigated whether 4-NP biomagnifies in marine ecological systems. In one Canadian wetland, Mayer and coworkers (2007) found that 4-NP from contaminated seawater and sediments accumulated in the tissues of benthic invertebrates, suggesting the potential to biomagnify in trophic chains. A more 
comprehensive field study in a coastal bay system in China found that tissue concentrations of 4-NP exhibited trophic dilution, rather than biomagnification, from invertebrates to fish and, ultimately, seabirds (Hu et al., 2005).

In the current study, we assessed bioaccumulation and biomagnification of 4-NP in the Morro Bay estuary of central California, USA, by quantifying 4-NP levels within the water, sediment and tissues of several marine organisms, and pairing that analysis with a stable isotope characterization of trophic status. Morro Bay is a relative small estuary $\left(9 \mathrm{~km}^{2}\right)$, located at the base of a $198-\mathrm{km}^{2}$ watershed with a low human population density (383 people $\mathrm{km}^{2}$ in 2010), and is considered an estuary in relatively good condition with low levels of most monitored contaminants, excepting phosphorus, mercury, DDT and occasional intrusions of fecal bacteria (EPA, 2006). Morro Bay wastewater receptacles were tested to assess their potential contribution of 4-NP to the estuary. 4-NP was found at unexpectedly high levels within several organisms inhabiting the estuary, prompting a secondary assessment to explore the extent of 4-NP contamination in marine organisms from several estuaries located along the West Coast of North America (USA and Canada). Estuaries are important ecosystems that function as nursery habitats for a number of commercially important species, and estuaries in proximity to human development are recognized as threatened by pollution via their role as receptacles for runoff and freshwater inputs from the entire watershed.

\section{Materials and methods}

\subsection{Sampling of organisms}

Organisms were sampled from four California estuaries: Morro Bay $\left(35^{\circ} 20.7^{\prime} \mathrm{N}, 120^{\circ} 50.7^{\prime} \mathrm{W}\right)$, San Francisco Bay $\left(37^{\circ} 40.5^{\prime} \mathrm{N}\right.$, $\left.122^{\circ} 17.3^{\prime} \mathrm{W}\right)$, Drakes Bay $\left(38^{\circ} 3.6^{\prime} \mathrm{N}, 122^{\circ} 56.1^{\prime} \mathrm{W}\right)$, and Tomales Bay $\left(38^{\circ} 7.3^{\prime} \mathrm{N}, 122^{\circ} 52.1^{\prime} \mathrm{W}\right)$; Netarts Bay, Oregon $\left(45^{\circ} 24.6^{\prime} \mathrm{N}\right.$, $123^{\circ} 56.3^{\prime} \mathrm{W}$ ); and Bamfield Inlet and Baynes Sound on Vancouver Island, British Columbia, Canada $\left(48^{\circ} 48.8^{\prime} \mathrm{N}, 125^{\circ} 9.4^{\prime} \mathrm{W}\right.$ and $49^{\circ} 37.6^{\prime} \mathrm{N}, 124^{\circ} 52.1^{\prime} \mathrm{W}$, respectively). The trophic relationships among species sampled in Morro Bay were putatively separated into a planktonic-based food chain and a littoral-based food chain (S1).

Arrow gobies (Clevelandia ios) from Morro Bay, CA (2006-2011), Tomales Bay, CA (September 2008), and Bamfield Inlet, Canada (November 2009), were collected from subsurface burrows with yabbie pumps. C. ios were collected from four sites in San Francisco Bay in fall of 2006 by the San Francisco Estuary Institute (SFEI): Point Isabel Regional Shoreline (near Berkeley, CA), Candlestick Point State Recreation Area (near San Francisco, CA), Martin Luther King Jr. Regional Shoreline (MLKJRS, near inner Oakland Harbor), and Bird Island (near Foster City, CA). Additional C. ios were collected from MLKJRS in October 2009. Samples were pooled according to collection site for chemical analysis.

Mussels (Mytilus californianus) were collected by hand from Morro Bay, CA (October 2010) and Bamfield, Canada (November 2009). Oysters (Crassostrea gigas) were purchased in October and December 2010 from commercial companies in Morro Bay, Drakes Bay, Tomales Bay, CA, Netarts Bay, OR, and Baynes Sound, BC. In October 2010, ghost shrimp (Neotrypaea californiensis) were collected by yabbie pump, a water column sample via $20 \mu \mathrm{m}$ vertical net tow, and benthic invertebrates with a $250 \mu \mathrm{m}$ sieve in Morro Bay. Staghorn sculpins (Leptocottus armatus) and Pacific sanddabs (Citharichthys sordidus) were collected by otter trawl in Morro Bay (August 2008).

Seabird livers were collected by Pacific Wildlife Care Morro Bay, during autopsy from piscivorous birds (grebes of the genus Aechmorphorus and Pacific loon Gavia pacifica) (November 2009,
December 2009 and January 2010). Marine mammal livers were collected by California Fish and Game (sea otters, Enhydra lutris nereis) (2007-2009), Santa Barbara Natural History Museum (harbor porpoise, Phocoena phocoena) (2008-2009), and the Marine Mammal Center in Sausalito, CA (California sea lion, Zalophus californianus) (2007 and 2009) during autopsy, then frozen at $80^{\circ} \mathrm{C}$. Interior $2 \mathrm{~g}$ sections were subsampled from mammal and bird livers, permitted by NOAA.

\subsection{Sampling of water and sediment}

Morro Bay sediment samples were collected at low tide between 0 and $2 \mathrm{~cm}$ depth with metal spoons, previously acetonesoaked for $5 \mathrm{~min}$ and heated to $300^{\circ} \mathrm{C}$ for $2 \mathrm{~h}$. Subsurface seawater was collected in UV-protected glass bottles from standing pools of water at low tide. Collections of sediment and seawater were made from five sites within Morro Bay in both 2008 and 2009.

Septic tanks were sampled in Los Osos, California, a community adjacent to Morro Bay, in November of 2008 and 2010. We sampled two community septic systems: Bayridge and Vista del Oro, servicing 186 and 89 homes respectively. The top biosolid layer, middle liquid portion, and bottom sludge layer (Bayridge only) were each captured using a collecting bucket on a pole, then stored in UV-protected glass bottles at $80^{\circ} \mathrm{C}$.

Raw influent and post-polymerization sludge were sampled in August 2008 and November 2010 from the California Men's Colony wastewater treatment plant (WWTP) whose discharge enters Chorro Creek then flows into Morro Bay. In addition, water and sediment samples were collected $100 \mathrm{~m}$ upstream and downstream of the discharge point according to the protocol above. Toilet paper samples were purchased from local stores.

\subsubsection{4-NP analyses}

Samples for chemical analysis were dissected with tools and glassware previously soaked in acetone for $5 \mathrm{~min}$, then heated at $300{ }^{\circ} \mathrm{C}$ for $2 \mathrm{~h}$. Digestive tissue was removed from whole fish, bivalve, and shrimp samples to avoid contamination from ingested sediment. Liver analyses were conducted on fish, bird, and mammal samples because 4-NP may accumulate in lipid-rich tissue, especially where foreign compounds are metabolized.

Organisms were tested individually, except for gobies, plankton and benthic copepod samples, where multiple individuals had to be pooled to obtain sufficient mass for analysis $(2 \mathrm{~g})$. C. ios samples contained between 2 and 10 gobies. Tissues were stored in EPA certified glass vials at $80^{\circ} \mathrm{C}$ and analyzed at Mississippi State Chemical Laboratory (MSCL).

At MSCL, samples were extracted, purified, and quantified for 4-NP by GC-MS based on the methods of Das and Xia (2008) for biological samples and Keller et al. (2003) for water samples. All isomers of 4-NP detected in the samples are included in reported concentration values. Detailed extraction, cleanup, and analysis procedures are described in the Supplemental information (S2).

\subsection{Stable isotope analysis}

Stable isotope analysis dissection tools and glassware were soaked in methanol for $5 \mathrm{~min}$, then heated at $500{ }^{\circ} \mathrm{C}$ overnight. Organisms were dissected on prepared glassware over ice. Digestive tissue was removed from fish, bivalve, and shrimp samples to avoid contamination from gut contents. Tissues were combusted for more than $48 \mathrm{~h}$ at $40^{\circ} \mathrm{C}$, ground to a fine powder, homogenized, and weighed in $1 \mathrm{mg}$ portions into tin boats. Samples were analyzed with a PDZ Europa ANCA-HSL elemental analyzer and a PDZ Europa 20-20 isotope ratio mass spectrometer (Sercon Ltd., UK) at the UC Davis Stable Isotope Facility for ${ }^{15} \mathrm{~N} /{ }^{14} \mathrm{~N}$ and ${ }^{13} \mathrm{C} /{ }^{12} \mathrm{C}$ analyses. Samples were analyzed for isotope 
ratios simultaneously by combustion at $1000^{\circ} \mathrm{C}$ in a reactor with chromium oxide and silvered cobaltous/cobaltic oxide, purification via reduction reactor (reduced copper at $650^{\circ} \mathrm{C}$ ) and a water trap of magnesium chlorate, then separation via Carbosieve GC column $\left(65^{\circ} \mathrm{C}, 65 \mathrm{~mL} \mathrm{~min}{ }^{1}\right)$ for entry to the isotope ratio mass spectrometer.

Species were analyzed ( $n=3$, except $n=1$ for sculpin and $n=2$ for porpoise) for ${ }^{15} \mathrm{~N} /{ }^{14} \mathrm{~N}$ and ${ }^{13} \mathrm{C} /{ }^{12} \mathrm{C}$ stable isotope ratios. Stable isotope abundance is expressed in permil units as $\delta X=\left[\left(R_{\text {sample }}\right)\right.$ $R_{\text {standard }}$ ) 1] $\times 1000$, where $R$ is the ratio of heavy to light isotopes, ${ }^{15} \mathrm{~N} /{ }^{14} \mathrm{~N}$ and ${ }^{13} \mathrm{C} /{ }^{12} \mathrm{C}$, for the corresponding $X$ value of ${ }^{15} \mathrm{~N}$ or ${ }^{13} \mathrm{C}$. The international standards used for $R_{\text {standard }}$ were air for nitrogen and Vienna PeeDee Belemnite for carbon. Long-term standard deviations of $\delta^{15} \mathrm{~N}$ and $\delta^{13} \mathrm{C}$ analyses were $0.3 \%$ for ${ }^{15} \mathrm{~N}$ and $0.2 \%$ for ${ }^{13} \mathrm{C}$. $\delta^{13} \mathrm{C}$ values were lipid normalized according to $\delta^{13} C_{\text {normalized }}=\delta^{13} C_{\text {untreated }}-3.32+0.99 \times \mathrm{C}: \mathrm{N}$ because all samples had C:N ratios greater than 3.5 (Post et al., 2007), except for two sanddab samples with $\mathrm{C}: \mathrm{N}=3.3$.

Trophic level (TL) calculations were based on the assumption that mussels occupy a TL of 2.5 , midway between primary and secondary consumer due to consumption of phyto- and zooplankton. The TL of other species was calculated with $\mathrm{TL}=2.5+\left(\delta^{15} \mathrm{~N}_{\text {consumer }}\right.$ $\left.\delta^{15} \mathrm{~N}_{\text {mussel }}\right) / \Delta_{n}$ (Post, 2002) assuming a trophic enrichment factor $\left(\Delta_{n}\right)$ of 3.4 (Post, 2002). Bioaccumulation from seawater to organisms was calculated for each species using wet weight NP concentrations, $\mathrm{BAF}_{\text {seawater }}=\mathrm{NP}_{\text {wet }}$ weight $/ \mathrm{NP}_{\text {seawater }}$. Accumulation from sediment to organisms was calculated with dry weight NP concentrations, $\mathrm{BAF}_{\text {sediment }}=\mathrm{NP}_{\text {dry weight }} / \mathrm{NP}_{\text {sediment }}$. To determine the biomagnification factor (BMF) between predator and prey species, lipid weight $\mathrm{NP}$ concentrations were used, $\mathrm{BMF}=\mathrm{NP}_{\text {predator }} / \mathrm{NP}_{\text {prey }}$. The trophic magnification factor (TMF) is calculated as the antilog of the slope of the regression line between the logarithm of the lipid weight NP concentration for each organism in the food web and its TL (Weisbrod et al., 2009).

\subsection{Statistical analyses}

All statistical tests were conducted with MiniTab (version 16). 4-NP levels in toilet paper were compared with Student's $t$-test. Comparisons of mean lipid weight concentration of 4-NP in goby, oyster, and mussel tissue among locations were tested using the Kruskal Wallace $h$ statistic, a one-way analysis of variance, and Student's $t$-test, respectively.

\section{Results}

\subsection{Trophic relationships in Morro Bay}

Mean stable isotope values for $\delta^{13} \mathrm{C}$ ranged from $24.1 \%$ to $12.2 \%$ for raw data and from $20.5 \%$ to $11.5 \%$ for lipid corrected data (Fig. 1). In general, the water column sample, oysters, and mussels had the most negative values of $\delta^{13} \mathrm{C}$, indicating a higher proportion of pelagic producers in their diets as compared to benthic species (invertebrates, goby, and sculpin), which had the least negative $\delta^{13} \mathrm{C}$ values. The water column sample contained zooplankton, phytoplankton, and detritus, and demonstrated a substantial shift in $\delta^{13} \mathrm{C}$ value with lipid correction (Fig. 1), perhaps due to its low $\mathrm{N}$ content $(17.3-24.3 \mu \mathrm{g})$ or the relative proportion of its constituents.

Mean $\delta^{15} \mathrm{~N}$ stable isotope values ranged from 9.4\%o to $18.5 \%$ with species distributed over five trophic levels (Fig. 1). In general, the calculated levels increased from bivalves and ghost shrimp through fish, mammals, and seabirds. However, the $\delta^{15} \mathrm{~N}$ abundance in the water column and benthic invertebrate samples placed them in trophic level three, higher than expected.

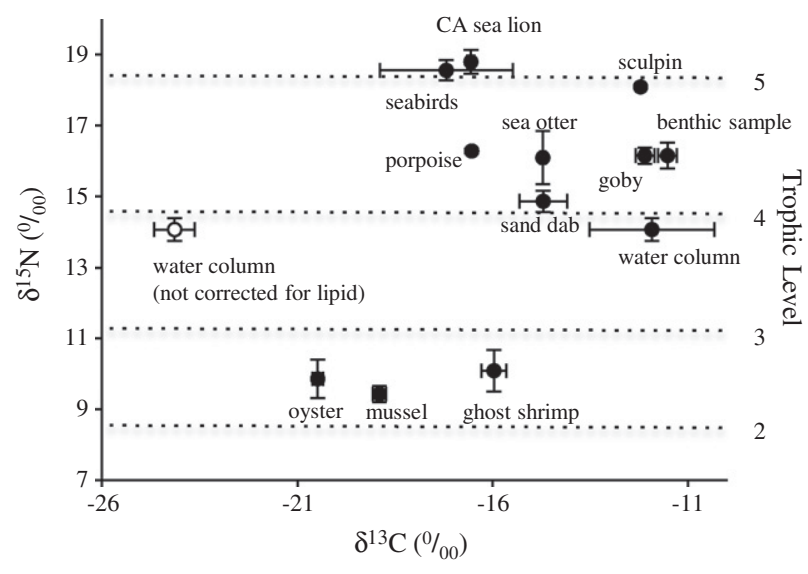

Fig. 1. Mean ( $\pm 1 \mathrm{SE})$ stable carbon (lipid-corrected) and nitrogen isotope abundance in organisms from the Morro Bay, CA food web. Trophic levels were calculated assuming mussels occupied TL 2.5. The single open data point was not corrected for lipid content.

\subsection{4-NP in the trophic system of Morro Bay}

The analysis of 4-NP concentration achieved $64-88 \%$ recovery for sediment/biosolids samples (MDL $0.01 \mathrm{mg} \mathrm{kg}^{1}$ ), $74-124 \%$ recovery for water samples (MDL $0.1 \mu \mathrm{g} \mathrm{L}{ }^{1}$ ), and $81-121 \%$ recovery for tissue samples (MDL $20 \mu \mathrm{g} \mathrm{kg}{ }^{1}$ ), except for sea otter livers (30\% recovery). Average percent lipid was $0.06 \pm 0.02$ for the water column samples, $0.13 \pm 0.03$ for benthic invertebrates and detritus, $8.5 \pm 2.6$ for ghost shrimp, $0.76 \pm 0.08$ for oysters, $0.94 \pm 0.20$ for mussels, $0.74 \pm 0.05$ for whole gobies, $3.3 \pm 1.1$ for fish livers, $3.8 \pm 0.70$ for mammal livers, and $1.6 \pm 0.35$ for seabird livers. Reported 4-NP concentrations are corrected by lipid content.

The concentration of 4-NP in seawater of Morro Bay did not exceed $0.9 \mu \mathrm{g} \mathrm{L}^{1}$ at any collection time, and it was most often present at the detection limit of $0.1 \mu \mathrm{g} \mathrm{L}{ }^{1}$, averaging $0.42 \pm$ $0.16 \mu \mathrm{g} \mathrm{L}{ }^{1}$. However, the 4-NP concentration in nine samples of sediment from five sites in Morro Bay ranged from undetected to $157 \mathrm{ng} \mathrm{g}{ }^{1}$, averaging $53 \pm 14 \mathrm{ng} g{ }^{1} 4-\mathrm{NP}(\mathrm{dw})$, and a single sample of eelgrass contained $33 \mathrm{ng} g{ }^{1} 4-\mathrm{NP}$ (ww). Whole organism tissues (oyster, mussel, goby, and ghost shrimp) contained 4-NP levels an order of magnitude higher than the sediment (Table 1).

Two staghorn sculpin, small fish that prey upon arrow gobies but otherwise have a similar diet to that of the arrow goby, had liver concentrations of 104000 and $174000 \mathrm{ng} \mathrm{g}{ }^{1} \mathrm{lw}$, higher than the average of the arrow goby liver samples, $52200 \pm 37500 \mathrm{ng} \mathrm{g}{ }^{1} \mathrm{lw}$. A piscivorous Pacific sanddab contained 4-NP at a concentration of $96200 \mathrm{ng} \mathrm{g}{ }^{1} \mathrm{lw}$ in the single liver sampled (Table 1 ).

Table 1

Concentration of 4-NP in Morro Bay species.

\begin{tabular}{lrccll}
\hline Organism & $n$ & $\begin{array}{l}4-\mathrm{NP} \\
\left(\mathrm{ng} \mathrm{g}^{1} \mathrm{lw}\right)\end{array}$ & $\begin{array}{l}4-\mathrm{NP} \\
\left(\mathrm{ng} \mathrm{g}^{1} \mathrm{ww}\right)\end{array}$ & $\begin{array}{l}\% \\
\text { Lipid }\end{array}$ & $\begin{array}{l}\% \\
\text { Moisture }\end{array}$ \\
\hline $\begin{array}{l}\text { Water } \\
\quad \text { column }\end{array}$ & 3 & $982000 \pm 657000$ & $432 \pm 233$ & $0.06 \pm 0.02$ & $91 \pm 1.8$ \\
Oyster & 3 & $62800 \pm 28500$ & $480 \pm 237$ & $0.76 \pm 0.08$ & $87 \pm 1.8$ \\
Mussel & 3 & $12700 \pm 1300$ & $122 \pm 35$ & $0.94 \pm 0.2$ & $82 \pm 0.3$ \\
Benthic & & & & & \\
invertebrates & 3 & $107000 \pm 57000$ & $103 \pm 28$ & $0.13 \pm 0.03$ & $51 \pm 5.8$ \\
Ghost shrimp & 3 & $24200 \pm 10000$ & $2380 \pm 1140$ & $8.5 \pm 2.6$ & $72 \pm 1.8$ \\
Arrow goby & 27 & $36100 \pm 6100$ & $237 \pm 36$ & $0.74 \pm 0.05$ & $80 \pm 1.0$ \\
Goby liver & 2 & $52200 \pm 37500$ & $2070 \pm 996$ & $5.4 \pm 2.0$ & $76 \pm 1.3$ \\
Sanddab liver & 1 & 96200 & 2920 & 3.03 & 63 \\
Sculpin liver & 2 & $139000 \pm 35200$ & $1760 \pm 50$ & $1.3 \pm 0.3$ & $83 \pm 7.6$ \\
Seabird liver & 3 & $15700 \pm 3600$ & $261 \pm 98$ & $1.6 \pm 0.4$ & $80 \pm 2.2$ \\
Sea lion liver & 3 & $25000 \pm 8600$ & $754 \pm 275$ & $3.0 \pm 0.7$ & $83 \pm 4.2$ \\
Porpoise liver & 3 & $14000 \pm 5600$ & $807 \pm 387$ & $6.0 \pm 1.3$ & $74 \pm 1.4$ \\
Sea Otter liver & 3 & $138000 \pm 55000$ & $3680 \pm 1610$ & $2.5 \pm 0.3$ & $77 \pm 1.0$ \\
\hline
\end{tabular}


Piscivorous seabirds contained lower levels of 4-NP in their livers than Morro Bay fish species, despite occupying a higher trophic level (Fig. 1 and Table 1). The livers of three female porpoise $\left(14000 \pm 5600 \mathrm{ng} \mathrm{g}{ }^{1} \mathrm{lw}\right)$ and three female California sea lions ( $25000 \pm 8600 \mathrm{ng} \mathrm{g}{ }^{1} \mathrm{lw}$ ) had similar concentrations of 4-NP to those found in seabird livers, but lower than the levels found in fish livers (Table 1). On the other hand, the livers of three female sea otters averaged the highest levels of 4-NP among Morro Bay mammals, $138000 \pm 55400 \mathrm{ng} \mathrm{g}{ }^{1} \mathrm{lw}$.

The water column and benthic invertebrate samples contained $982000 \pm 657000 \mathrm{ng} \mathrm{g}{ }^{1} \mathrm{lw}$ and $107000 \pm 57000 \mathrm{ng} \mathrm{g}{ }^{1} \mathrm{lw} 4-\mathrm{NP}$, respectively. These samples required rinsing via MilliQ $\left(0.35 \mu \mathrm{g} \mathrm{L}{ }^{1}\right.$ 4-NP) water in order to collect detritus and organisms from the sieve.

\subsection{Biomagnification in Morro Bay}

Accepted criteria for evidence of bioaccumulation are BAF values greater than $5000 \mathrm{~L} \mathrm{~kg}{ }^{1}$, BMF values great than one, or TMF greater than one (Weisbrod et al., 2009). The BAF values for Morro Bay species relative to seawater were less than 5000 for all species except for ghost shrimp, the piscivorous fish group, and sea otters (Table 2). None of the BAF values relative to sediment were greater than 319 . Lipid-corrected BMF values indicated biomagnification from bivalves (mussels and oysters) to otter livers as well as from goby livers to piscivorous fish (sanddab and sculpin) livers (Table 2).

The linear regression between trophic level and the log of the lipid weight concentration of NP in organisms of Morro Bay does not indicate bioaccumulation (Fig. 2). The TMF for all species associated with Morro Bay is 1.1, and the TMF for species that are constant residents of the bay (excluding birds and mammals) is 1.9; however, neither of these regression relationships are significant, $p=0.81$ and $p=0.21$, respectively.

\subsection{NP associated with wastewater near Morro Bay}

Chorro Creek, which flows into Morro Bay, had statistically indistinguishable levels of 4-NP in the stream water and sediment

Table 2

Biomagnification Factors (BMF) of 4-NP (lipid weight) between predator/prey pairs and Bioaccumulation Factors (BAF) for Morro Bay species relative to seawater (wet weight) and sediment (dry weight) 4-NP concentrations. Bold values exceed critical values for bioaccumulation.

\begin{tabular}{lll}
\hline Predator & Prey & BMF $_{\text {lipid }}$ \\
\hline Oyster & Water column & 0.1 \\
Mussel & Water column & 0 \\
Otter liver & Oyster & $\mathbf{2 . 2}$ \\
Otter liver & Mussel & $\mathbf{1 0 . 9}$ \\
Ghost shrimp & Benthic invertebrates & 0.2 \\
Goby & Benthic invertebrates & 0.3 \\
Sculpin liver & Goby liver & $\mathbf{2 . 7}$ \\
Seabird liver & Sanddab/sculpin livers & 0.1 \\
Seabird liver & Goby liver & 0.3 \\
Porpoise liver & Sanddab/sculpin livers & 0.1 \\
Sea lion liver & Sanddab/sculpin livers & 0.2 \\
\hline Organism & BAF & BAF \\
seawater & 93 \\
Water column & 1029 & 10 \\
Benthic invertebrates & 245 & 152 \\
Ghost shrimp & $\mathbf{5 6 6 7}$ & 27 \\
Goby & 564 & 166 \\
Goby liver & 4929 & 212 \\
Sanddab/sculpin livers & $\mathbf{5 1 0 4}$ & 25 \\
Seabird liver & 621 & 63 \\
Oyster & 1143 & 12 \\
Mussel & 290 & 319 \\
Otter liver & $\mathbf{8 7 6 2}$ & 62 \\
Porpoise liver & 1921 & 99 \\
Sea lion liver & 1795 & \\
\hline
\end{tabular}

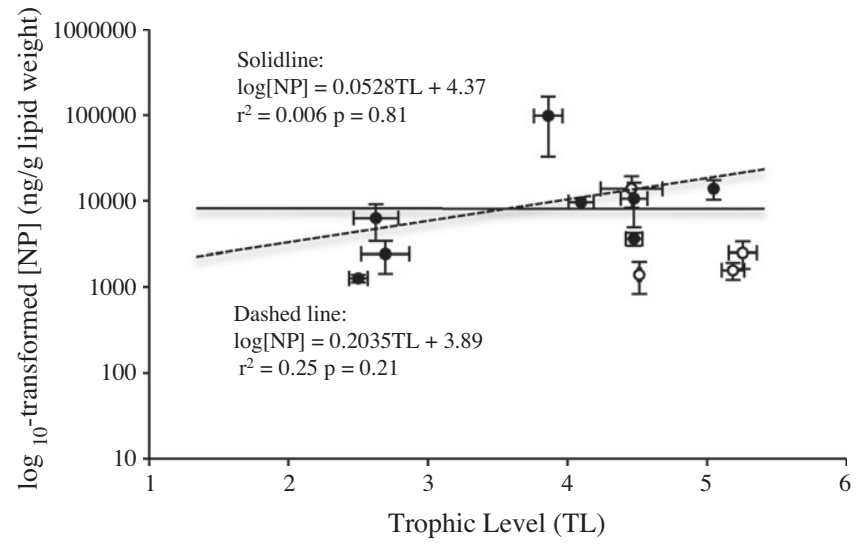

Fig. 2. The linear relationship between log-transformed lipid-weight NP concentrations and the trophic level of organisms from Morro Bay. The solid regression line is derived from all the data on the figure, and the dashed regression line is determined from only the solid circles, omitting the white circles (mammal and bird data).

at $100 \mathrm{~m}$ upstream and downstream sites from the WWTP discharge point ( $t$-tests, $p>0.05$ ) (Table 3 ). A lower 4-NP concentration was measured in raw influent than exited in dewatered sludge ( $t$-test, $p=0.03$ ) (Table 3 ). Local community septic tanks in Los Osos, CA, adjacent to Morro Bay, had higher levels of 4-NP in the upper solid layers than in the liquid portions of the tanks (Table 3). The sludge that accumulated on the bottom of the septic tanks at Bayridge had 4-NP concentrations ranging from 214 to $7930 \mathrm{mg} \mathrm{kg}^{1}$ (dw) (Table 3).

We analyzed six types of toilet paper for 4-NP and found that three brands made from $100 \%$ virgin wood pulp contained $367 \pm 214 \mathrm{ng} \mathrm{g}{ }^{1} \mathrm{dw}$ NP, less than three environmentally-friendly brands made from $100 \%$ recycled paper with $80 \%$ or $90 \%$ postconsumer waste, $1720 \pm 320 \mathrm{ng} \mathrm{g}{ }^{1} \mathrm{dw} \mathrm{NP}$ ( $t$-test, $p=0.02$, data not shown).

\subsection{NP in other west coast estuaries}

Mean 4-NP levels were similar for oysters in five west coast estuaries regardless of local population density or nearby industries or agriculture (ANOVA, $f_{4,10}=0.57, p=0.69$ ), but differed for gobies and mussels (Table 4). 4-NP levels in California mussels were greater in Morro Bay, CA than Bamfield, BC, Canada (Table 4; $t$-test, $t_{4}=4.48, p=0.01$ ). Average ranked concentrations of 4-NP in arrow gobies were not consistent among four West coast bays (Table 4; Kruskal-Wallis $h_{3}=9.01, p=0.03$ ). Nonparametric pairwise comparisons (Zar, 1996) grouped Morro Bay and Tomales Bay separately from Bamfield and San Francisco Bay (Dunn's test, $p<0.05$ ).

\section{Discussion}

\subsection{NP pathways in Morro Bay}

This study is the first to report that 4-NP is present in Morro Bay at several trophic levels. The levels of 4-NP increased from seawater to sediment to organisms and increased in some, but not all organisms, towards the highest trophic level, e.g. bivalves to sea otters (Table 2). To place the levels of 4-NP in Morro Bay relative to worldwide bays and estuaries, we expanded a comparison table created by David et al. (2009); data are presented as reported in the cited references (S3), except that we converted 4-NP concentrations for organisms to lipid weight when percent lipid data were available (Table 5). Seawater and sediment in Morro Bay contained lower levels of 4-NP than most other estuaries worldwide (Table 5). 
Table 3

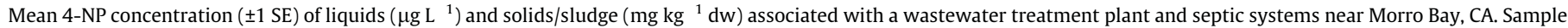
sizes are in parentheses.

\begin{tabular}{|c|c|c|c|}
\hline Wastewater receptacles & Solids & Liquid & Sludge \\
\hline \multicolumn{4}{|l|}{ Septic systems (Los Osos Community) } \\
\hline Bayridge & $50 \pm 35(3)$ & $22.1 \pm 5.8(4)$ & $3750 \pm 2250(3)$ \\
\hline \multirow[t]{2}{*}{ Vista Del Oro } & $6270 \pm 5520(3)$ & $48.8 \pm 6.5(3)$ & \\
\hline & Liquid & Sediment/Solids & \\
\hline \multicolumn{4}{|l|}{ WWTP and Chorro Creek } \\
\hline Raw influent & $17.5 \pm 1.8(3)$ & & \\
\hline $100 \mathrm{~m}$ upstream of discharge point & $1.8 \pm 1.3(3)$ & $0.03 \pm 0.03(3)$ & \\
\hline $100 \mathrm{~m}$ downstream of discharge point & $1.0 \pm 0.3(3)$ & $0.22 \pm 0.16(3)$ & \\
\hline Dewatered sludge & & $0.72 \pm 0.28(3)$ & \\
\hline
\end{tabular}

Table 4

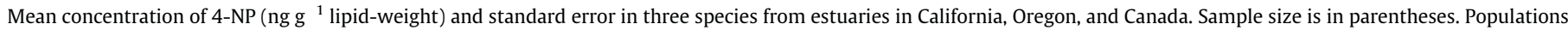
with significantly different means are indicated with different letters $(p<0.05)$.

\begin{tabular}{|c|c|c|c|c|c|c|}
\hline & Clevelandia ios & Mytilus californianus & Crassostrea gigas & Estuary area $\left(\mathrm{km}^{2}\right)$ & Watershed area $\left(\mathrm{km}^{2}\right)$ & Watershed population \\
\hline Morro Bay, CA, USA & $36100 \pm 6100(27)^{\mathrm{a}}$ & $12700 \pm 1300(3)^{\mathrm{a}}$ & $62800 \pm 28400(3)$ & 9 & 198 & 25500 \\
\hline San Francisco Bay, CA, USA & $11100 \pm 3800(6)^{b}$ & & & 4144 & 155,400 & 7 million \\
\hline Drakes Bay, CA, USA & & & $24800 \pm 8400(3)$ & 8 & 31 & 1421 \\
\hline Tomales Bay, CA, USA & $40100 \pm 14900(6)^{a}$ & & $48700 \pm 18800(3)$ & 28 & 560 & 202 \\
\hline Netarts Bay, OR, USA & & & $40700 \pm 18100(3)$ & 9.4 & 36.3 & 744 \\
\hline Bamfield Inlet, BC, Canada & $9000 \pm 900(4)^{b}$ & $6100 \pm 700(3)^{b}$ & & 1.28 & & 250 \\
\hline Baynes Sound, BC, Canada & & & $37900 \pm 13000(3)$ & 150 & & 60000 \\
\hline
\end{tabular}

However, the concentrations of 4-NP in the organisms of Morro Bay relative to those of organisms worldwide is influenced by the units in which 4-NP concentration is reported: lipid weight, dry weight, or wet weight (Table 5).

Estuarine sediment is particularly likely to retain 4-NP due to its slow rate of degradation, with a half-life of years to decades, under anaerobic conditions (Ying et al., 2002). In the case of Morro Bay, mud-dwelling organisms may act as a common entry route of 4NP into the trophic chain (David et al., 2009). The levels of 4-NP in arrow gobies from Morro Bay and Tomales Bay are higher than levels of 4-NP in marine fish species from China, when the concentration of 4-NP is measured in lipid weight (Table 5). On the other hand, the comparison of 4-NP in Californian gobies to Italian marine fish has drastically different results depending on the measurement used; wet weight 4-NP concentrations are greater in Californian gobies, but for the same fish, the lipid weight 4-NP concentrations are comparable to Italian fish (Table 5). In addition, Morro Bay gobies have higher wet weight 4-NP levels than all of the freshwater fish measured in other studies (Table 5). Staghorn sculpins prey upon arrow gobies (West et al., 2003) and, in Morro Bay, sculpins are at a higher trophic level than gobies (Fig. 1); the BMF between the two fishes based on 4-NP liver concentrations is 2.7 (Table 2), indicating biomagnification.

Plankton and detritus samples filtered from the Morro Bay water column contained the highest mean level of 4-NP among tissue samples (Table 1) despite the low levels of 4-NP in seawater; however, 4-NP did not further accumulate in Morro Bay filter feeders: oysters and mussels (Table 2). Selective filtration may prevent components of the water column rich in 4-NP, such as detritus, from being ingested by bivalves, or bivalves may have efficient mechanisms for rapid depuration of 4-NP from high levels (Gatidou et al., 2010). Compared to other locations, oysters in Morro Bay have higher 4-NP levels than other US estuaries (except for Drakes Bay) but lower than Asian estuaries (Table 5). On the other hand, Morro Bay mussels contain more 4-NP than most mussels from Europe and Asia using either a dry-weight or lipid-weight measure.

In Morro Bay, levels of 4-NP in liver tissue were lower in marine mammals and birds than in fish, consistent with the trophic dilution of 4-NP observed by Hu et al. (2005) (Table 1). We did not find any studies that reported 4-NP levels in marine mammals, and the mean 4-NP concentrations in Morro Bay bird livers is higher than that in bird livers from two other estuaries (Table 5). Some of these higher-order consumers use Morro Bay transiently, such as seabirds, porpoise, CA sea lions, and sea otters, but biomagnification was not apparent after removing transient species from the analysis (Fig. 2). The marine mammal that tends to remain local, the sea otter, had the highest concentration of 4-NP in liver tissue of any organism tested, $240000 \mathrm{ng} \mathrm{g}{ }^{1} \mathrm{lw}$. Although we have not established a direct trophic link between our sea otter samples and bivalve samples, the otter liver samples came from animals that were likely residents of Morro Bay. In addition, the bulk of the sea otters' diet consists of a variety of invertebrates, such as sea urchins, bivalves, and gastropods, placing them in a different trophic pathway than the other marine mammals, which consume mainly fish and cephalopods. An additional factor that may contribute to the reduced levels of 4-NP in some marine mammals in comparison to fish is the higher clearance rate for 4-NP that distinguishes mammalian from fish hepatocytes (Han et al., 2007).

Measurements of 4-NP levels from septic systems adjacent to Morro Bay and river sediment near a WWTP suggest that there are potential sources for continuous input of 4-NP into the bay. Concentrations of 4-NP were observed to be especially high in the anaerobic sludge layer of septic tanks, compared to WWTP sludge (Tables 3 and 5); the septic sludge had been accumulating for 8 years, likely illustrating both the affinity and persistence of 4-NP in sediments with anaerobic conditions. The liquid portion of the septage is pumped to a leach field atop a hill adjacent to the bay where it can contaminate the bay's waters through underground drainage as well as wind and rain erosion. Effluent of a WWTP discharging into a tributary of Morro Bay may be a source of 4-NP (Table 3). 4-NP was at a lower concentration in raw influent than in dewatered sludge at the WWTP (Table 3) likely related to increasing 4-NP levels from nonylphenol ethoxylate degradation during wastewater treatment processes (Keller et al., 2003).

\subsection{Occurrence of 4-NP in Pacific coast estuaries}

We extended our survey of 4-NP levels of marine organisms beyond Morro Bay to examine the range of variation in 4-NP contam- 
Table 5

4-NP concentrations in estuarine seawater and sediment, marine bivalves and fish, freshwater fish, bird livers, and wastewater or septage. References in Supplementa information (S3). na = not available.

\begin{tabular}{|c|c|c|}
\hline Location & NP (units) & Reference \\
\hline Seawater & NP (ug L $\left.{ }^{1}\right)$ & \\
\hline Singapore & $0.02-2.76$ & $\begin{array}{l}\text { Basheer et al. } \\
(2004)\end{array}$ \\
\hline UK estuaries & $0.1-2.6$ & $\begin{array}{l}\text { Blackburn et al. } \\
\text { (1999) }\end{array}$ \\
\hline Dutch estuaries & $0.03-0.93$ & $\begin{array}{l}\text { Jonkers et al. } \\
\text { (2003) }\end{array}$ \\
\hline Greek coast & $0.18-0.92$ & $\begin{array}{l}\text { Arditsoglou and } \\
\text { Voutsa (2008) }\end{array}$ \\
\hline Morro Bay, CA, USA & 0.42 & Present study \\
\hline Jamaica Bay, NY, USA & $0.08-0.42$ & $\begin{array}{l}\text { Ferguson et al. } \\
\text { (2001) }\end{array}$ \\
\hline Taiwanese coast & $0.29-0.37$ & $\begin{array}{l}\text { Cheng et al. } \\
\text { (2006) }\end{array}$ \\
\hline Hong Kong & $0.01-0.27$ & $\begin{array}{l}\text { Kueh and Lam } \\
\text { (2008) }\end{array}$ \\
\hline Venice Lagoon, Italy & $0.004-0.21$ & $\begin{array}{l}\text { Pojana et al. } \\
\text { (2007) }\end{array}$ \\
\hline Masan Bay, Korea & $0.01-0.21$ & Li et al. (2008) \\
\hline San Francisco Bay, CA & $0.01-0.07$ & $\begin{array}{l}\text { Hoenicke et al. } \\
\text { (2007) }\end{array}$ \\
\hline North Sea, German Bight & $0.001-0.03$ & $\begin{array}{l}\text { Bester et al. } \\
(2001)\end{array}$ \\
\hline
\end{tabular}

\begin{tabular}{|c|c|c|c|}
\hline Sediment & $\begin{array}{l}\mathrm{NP} \\
\left(\mathrm{ng} g{ }^{1} \mathrm{dw}\right)\end{array}$ & & \\
\hline Southern California Bight & $122-3200$ & & $\begin{array}{l}\text { Schlenk et al. } \\
\text { (2005) }\end{array}$ \\
\hline Hong Kong & $94-2900$ & & $\begin{array}{l}\text { Kueh and Lam } \\
\text { (2008) }\end{array}$ \\
\hline Dutch estuaries & $0.9-1080$ & & $\begin{array}{l}\text { Jonkers et al. } \\
\text { (2003) }\end{array}$ \\
\hline Jamaica Bay, USA & $7-700$ & & $\begin{array}{l}\text { Ferguson et al. } \\
\text { (2001) }\end{array}$ \\
\hline Masan Bay, Korea & $92-557$ & & Li et al. (2008) \\
\hline Masan Bay, Korea & $24-504$ & & $\begin{array}{l}\text { Hong et al. } \\
\text { (2009) }\end{array}$ \\
\hline Bohai Bay, China & $11-260$ & & $\begin{array}{l}\text { Wang et al. } \\
(2010)\end{array}$ \\
\hline Venice Lagoon, Italy & $47-192$ & & $\begin{array}{l}\text { Pojana et al. } \\
\text { (2007) }\end{array}$ \\
\hline Taiwanese coast & $130-190$ & & $\begin{array}{l}\text { Cheng et al. } \\
\text { (2006) }\end{array}$ \\
\hline $\begin{array}{l}\text { Northern Yellow Sea, } \\
\text { China }\end{array}$ & $10-130$ & & $\begin{array}{l}\text { Wang et al. } \\
\text { (2010) }\end{array}$ \\
\hline Estuary in Savannah, USA & $0.3-78$ & & $\begin{array}{l}\text { Senthil Kumar } \\
\text { et al. (2008) }\end{array}$ \\
\hline Liaodong Bay, China & $8.8-74$ & & $\begin{array}{l}\text { Wang et al. } \\
(2010)\end{array}$ \\
\hline Thau Lagoon, France & $2.8-70$ & & $\begin{array}{l}\text { Hong et al. } \\
\text { (2009) }\end{array}$ \\
\hline North Sea, German Bight & $13-55$ & & $\begin{array}{l}\text { Bester et al. } \\
\text { (2001) }\end{array}$ \\
\hline Morro Bay, CA, USA & 53 & & Present study \\
\hline Bohai Bay, China & $3.4-34.3$ & & Jin et al. (2008) \\
\hline Laizhou Bay, China & $13-32$ & & $\begin{array}{l}\text { Wang et al. } \\
(2010)\end{array}$ \\
\hline San Francisco Bay, CA & $<5$ & & $\begin{array}{l}\text { Hoenicke et al. } \\
(2007)\end{array}$ \\
\hline Oysters & $\begin{array}{l}\mathrm{NP} \\
(\mathrm{ng} g \\
\end{array}$ & $\begin{array}{l}\text { NP } \\
\text { (ng g }{ }^{1} \text { lipid) }\end{array}$ & \\
\hline Drakes Bay, CA, USA & 11200 & 24900 & Present study \\
\hline Chinese Bays & $67-7600$ & $636-63300$ & $\begin{array}{l}\text { Wang et al. } \\
(2010)\end{array}$ \\
\hline Taiwanese Coast & $130-5190$ & na & $\begin{array}{l}\text { Cheng et al. } \\
\text { (2006) }\end{array}$ \\
\hline $\begin{array}{l}\text { Baynes Sound, BC, } \\
\text { Canada }\end{array}$ & 4100 & 37900 & Present study \\
\hline Morro Bay, CA, USA & 3370 & 62800 & Present study \\
\hline Netarts Bay, OR, USA & 2440 & 40700 & Present study \\
\hline Tomales Bay, CA, USA & 1710 & 48700 & Present study \\
\hline San Francisco Bay, CA & 21.5 & na & $\begin{array}{l}\text { Hoenicke et al. } \\
\text { (2007) }\end{array}$ \\
\hline
\end{tabular}

Table 5 (continued)

\begin{tabular}{|c|c|c|c|}
\hline Location & NP (units) & & Reference \\
\hline Savannah, GA, USA & $1.5-20$ & $0.4-16.6$ & $\begin{array}{l}\text { Senthil Kumar } \\
\text { et al. (2008) }\end{array}$ \\
\hline Mussels & $\begin{array}{l}\text { NP } \\
\left(\mathrm{ng}^{1}{ }^{1} \mathrm{dw}\right)\end{array}$ & $\begin{array}{l}\text { NP } \\
\text { (ng g }{ }^{1} \text { lipid) }\end{array}$ & \\
\hline Bay of Toyko & $47-1350$ & $610-19600$ & $\begin{array}{l}\text { Isobe et al. } \\
(2007)\end{array}$ \\
\hline Aegean Sea, Greece & $117-914$ & na & $\begin{array}{l}\text { Gatidou et al. } \\
(2010)\end{array}$ \\
\hline Malaysian Coast & $18-663$ & $410-9340$ & $\begin{array}{l}\text { Isobe et al. } \\
(2007)\end{array}$ \\
\hline Morro Bay, CA, USA & 660 & 12700 & Present study \\
\hline Indonesian Coast & $75-643$ & $938-13100$ & $\begin{array}{l}\text { Isobe et al. } \\
(2007)\end{array}$ \\
\hline $\begin{array}{l}\text { Bamfield Inlet, BC, } \\
\text { Canada }\end{array}$ & 634 & 6100 & Present study \\
\hline Singapore Coast & 605 & 5450 & $\begin{array}{l}\text { Isobe et al. } \\
(2007)\end{array}$ \\
\hline $\begin{array}{l}\text { Mediterranean Coast, } \\
\text { Spain }\end{array}$ & $35-600$ & na & $\begin{array}{l}\text { Bouzas et al. } \\
(2010)\end{array}$ \\
\hline Philipinne Coast & $457-578$ & $4800-8750$ & $\begin{array}{l}\text { Isobe et al. } \\
(2007)\end{array}$ \\
\hline Masan Bay, Korea & $51-290$ & na & Li et al. (2008) \\
\hline Masan Bay, Korea & $51-289$ & na & $\begin{array}{l}\text { Hong et al. } \\
\text { (2009) }\end{array}$ \\
\hline Venice lagoon, Italy & $115-240$ & na & $\begin{array}{l}\text { Pojana et al. } \\
(2007)\end{array}$ \\
\hline Indian Coast & $72-202$ & $910-6600$ & $\begin{array}{l}\text { Isobe et al. } \\
(2007)\end{array}$ \\
\hline Thailand Coast & 201 & $1690-4070$ & $\begin{array}{l}\text { Isobe et al. } \\
(2007)\end{array}$ \\
\hline Vietnamese Coast & $94-121$ & 1980-2040 & $\begin{array}{l}\text { Isobe et al. } \\
(2007)\end{array}$ \\
\hline Cambodian Coast & $27-92$ & $240-1260$ & $\begin{array}{l}\text { Isobe et al. } \\
(2007)\end{array}$ \\
\hline Thau Lagoon, France & $32-42$ & na & $\begin{array}{l}\text { Hong et al. } \\
(2009)\end{array}$ \\
\hline San Francisco Bay, CA & $1.0-9.7$ & na & $\begin{array}{l}\text { Hoenicke et al. } \\
(2007)\end{array}$ \\
\hline Marine Fishes & $\begin{array}{l}\text { NP } \\
\left(\text { ng g }{ }^{1} \text { ww) }\right.\end{array}$ & $\begin{array}{l}\text { NP } \\
\text { (ng g }{ }^{1} \text { lipid) }\end{array}$ & \\
\hline $\begin{array}{l}\text { Arrow Goby, Morro Bay, } \\
\text { CA, USA }\end{array}$ & 237 & 36100 & Present study \\
\hline $\begin{array}{l}\text { Arrow Goby, Tomales } \\
\text { Bay, CA, USA }\end{array}$ & 221 & 40100 & Present study \\
\hline $\begin{array}{l}\text { Arrow Goby, San } \\
\text { Francisco, CA, USA }\end{array}$ & 176 & 11100 & Present study \\
\hline $\begin{array}{l}\text { Arrow Goby, Bamfield } \\
\text { Inlet, BC, Canada }\end{array}$ & 119 & 9000 & Present study \\
\hline Mackerels, Italy & $7-75$ & $609-18800$ & $\begin{array}{l}\text { Ferrara et al. } \\
(2008)\end{array}$ \\
\hline Mullets, Italy & $12-41$ & $1200-2400$ & $\begin{array}{l}\text { Ferrara et al. } \\
(2008)\end{array}$ \\
\hline Seabreams, Italy & $5-32$ & $3400-53000$ & $\begin{array}{l}\text { Ferrara et al. } \\
(2008)\end{array}$ \\
\hline Hake, Italy & $11-30$ & $2400-17000$ & $\begin{array}{l}\text { Ferrara et al. } \\
(2008)\end{array}$ \\
\hline Anchovies, Italy & $5-10$ & $7100-25000$ & $\begin{array}{l}\text { Ferrara et al. } \\
(2008)\end{array}$ \\
\hline Mullet, Bohai Bay, China & na & 325 & Hu et al. (2005) \\
\hline $\begin{array}{l}\text { Wolffish, Bohai Bay, } \\
\text { China }\end{array}$ & na & 309 & Hu et al. (2005) \\
\hline Weever, Bohai Bay, China & na & 278 & Hu et al. (2005) \\
\hline $\begin{array}{l}\text { Bartail Flathead, Bohai } \\
\text { Bay, China }\end{array}$ & na & 197 & Hu et al. (2005) \\
\hline $\begin{array}{c}\text { White Flower Croaker, } \\
\text { Bohai Bay, China }\end{array}$ & na & 177 & Hu et al. (2005) \\
\hline Catfish, Bohai Bay, China & na & 151 & Hu et al. (2005) \\
\hline Freshwater Fishes & $\begin{array}{l}\text { NP } \\
\left(\text { ng g }^{1} \text { ww) }\right.\end{array}$ & & \\
\hline $\begin{array}{l}\text { Arrow Goby, Morro Bay, } \\
\text { CA (for comparison) }\end{array}$ & 237 & & Present study \\
\hline $\begin{array}{l}\text { Common Carp, Lake } \\
\text { Mead, NV }\end{array}$ & 184 & & $\begin{array}{l}\text { Snyder et al. } \\
(2001)\end{array}$ \\
\hline $\begin{array}{l}\text { Flounder, } \\
\text { Tees Estuary, UK }\end{array}$ & $30-180$ & & Lye et al. (1999) \\
\hline
\end{tabular}


Table 5 (continued)

\begin{tabular}{|c|c|c|}
\hline Location & NP (units) & Reference \\
\hline $\begin{array}{l}\text { Common Carp, Cuyahoga } \\
\text { River, Ohio }\end{array}$ & $6.6-110$ & $\begin{array}{l}\text { Rice et al. } \\
\text { (2003) }\end{array}$ \\
\hline $\begin{array}{l}\text { Flounder, Tyne Estuary, } \\
\text { UK }\end{array}$ & $5-55$ & Lye et al. (1999) \\
\hline $\begin{array}{r}\text { Bluegill Sunfish, } \\
\text { Michigan, US }\end{array}$ & $3.3-29.1$ & $\begin{array}{l}\text { Kannan et al. } \\
\text { (2003) }\end{array}$ \\
\hline Beam, German Rivers & $2.1-15.3$ & $\begin{array}{l}\text { Wenzel et al. } \\
\text { (2004) }\end{array}$ \\
\hline Rock Bass, Michigan, US & 8.1 & $\begin{array}{l}\text { Keith et al. } \\
\text { (2001) }\end{array}$ \\
\hline $\begin{array}{l}\text { Rainbow Smelt, } \\
\text { Michigan, US }\end{array}$ & 7.7 & $\begin{array}{l}\text { Keith et al. } \\
(2001)\end{array}$ \\
\hline $\begin{array}{l}\text { White Sucker, Michigan, } \\
\text { US }\end{array}$ & 7.2 & $\begin{array}{l}\text { Keith et al. } \\
\text { (2001) }\end{array}$ \\
\hline $\begin{array}{l}\text { Smallmouth Bass, } \\
\text { Michigan, US }\end{array}$ & 5.8 & $\begin{array}{l}\text { Keith et al. } \\
(2001)\end{array}$ \\
\hline $\begin{array}{l}\text { Bluegill Sunfish, } \\
\text { Michigan, US }\end{array}$ & 5.7 & $\begin{array}{l}\text { Keith et al. } \\
(2001)\end{array}$ \\
\hline Bird Livers & $\begin{array}{l}\mathrm{NP} \\
\left(\mathrm{ng}{ }^{1} \text { ww) }\right.\end{array}$ & \\
\hline $\begin{array}{l}\text { Grebes and Loon, Morro } \\
\text { Bay, CA, US }\end{array}$ & $136-455$ & Present study \\
\hline $\begin{array}{l}\text { Surf Scoter, Vancouver } \\
\text { Island, BC }\end{array}$ & $0.7-191$ & $\begin{array}{l}\text { Wilson et al. } \\
(2010)\end{array}$ \\
\hline $\begin{array}{l}\text { Tree Swallow nestling, } \\
\text { Vancouver, BC }\end{array}$ & $29.5-38$ & $\begin{array}{l}\text { Dods et al. } \\
(2005)\end{array}$ \\
\hline Septage & $\mathrm{NP}\left(\mu \mathrm{g} \mathrm{L}^{1}\right)$ & \\
\hline Morro Bay, CA, USA & $22.1-48.8$ & Present study \\
\hline Cape Cod, MA, US & $10-16$ & $\begin{array}{l}\text { Swartz et al. } \\
(2006)\end{array}$ \\
\hline Raw Influent & $N P\left(\mu g L^{1}\right)$ & \\
\hline Kansas, US & $3390-16900$ & Xia et al. (2001) \\
\hline Indiana, US & 96.4 & $\begin{array}{l}\text { Klečka et al. } \\
(2010)\end{array}$ \\
\hline Cape Cod, MA, US & $25-33$ & $\begin{array}{l}\text { Rudel et al. } \\
\text { (1998) }\end{array}$ \\
\hline Morro Bay, CA, USA & $14.8-21$ & Present study \\
\hline Ohio, US & $3.3-9.3$ & $\begin{array}{l}\text { Klečka et al. } \\
(2010)\end{array}$ \\
\hline $\begin{array}{c}\text { Wastewater Treatment } \\
\text { Plant/Septic Sludge }\end{array}$ & $\begin{array}{l}\text { NP } \\
\left(\mathrm{mg} \mathrm{kg}{ }^{1} \mathrm{dw}\right)\end{array}$ & \\
\hline $\begin{array}{l}\text { Septic Tank, Morro Bay, } \\
\text { CA, US }\end{array}$ & 3750 & Present study \\
\hline $\begin{array}{l}\text { Canadian Wastewater } \\
\text { Treatment Plant }\end{array}$ & $4.6-1230$ & $\begin{array}{l}\text { Lee and Peart } \\
(2002)\end{array}$ \\
\hline $\begin{array}{l}\text { Andalusia, Spain } \\
\text { Wastewater } \\
\text { Treatment Plant }\end{array}$ & $0.9-358$ & $\begin{array}{l}\text { Gonzalez et al. } \\
\text { (2009) }\end{array}$ \\
\hline $\begin{array}{l}\text { Kansas, US Wastewater } \\
\text { Treatment Plant }\end{array}$ & $1.24-300$ & Xia et al. (2001) \\
\hline $\begin{array}{l}\text { Wastewater Treatment } \\
\text { Plant, Morro Bay, CA, } \\
\text { US }\end{array}$ & $0.23-1.2$ & Present study \\
\hline
\end{tabular}

ination among several estuaries along the west coasts of the USA and Canada. Our sites range from Bamfield Inlet, which has the smallest estuary $\left(1.28 \mathrm{~km}^{2}\right)$ and low urbanization, through San Francisco Bay, which has the most urbanized watershed and the largest estuary $\left(4144 \mathrm{~km}^{2}\right)$ (Table 4 ).

Average levels of 4-NP in arrow gobies from three estuaries in California and one in British Columbia ranged from 9000 to $40100 \mathrm{ng} \mathrm{g}{ }^{1} \mathrm{lw}$ (Table 4). Average 4-NP levels in arrow gobies were lowest at the least populated site, Bamfield Inlet in British Columbia, but the 4-NP levels were not statistically different from those of gobies in the most urbanized bay sampled in California, San Francisco Bay. A possible confounding factor was that the gobies from San Francisco Bay contained younger individuals than those from other bays, with significantly smaller mean size of $28.7 \pm 8 \mathrm{~mm}$ versus $46.7 \pm 4.7 \mathrm{~mm}, 46.4 \pm 6.8 \mathrm{~mm}$, and $42.9 \pm$ $4 \mathrm{~mm}$ for Morro Bay, Bamfield, and Tomales Bay, respectively
(ANOVA, $F_{3,108}=67.91, p<0.01$ ). Tomales and Morro Bay gobies have similar 4-NP concentrations despite the differences in watershed human population and geographical size. Mussels from Morro Bay have higher 4-NP levels than mussels from the smaller, more remote Bamfield site (Table 4). The mussels in Bamfield were on a more exposed intertidal section of the coast than the mussels from Morro Bay. Oysters, all of which grew suspended in the water column by commercial growers, show no difference in 4-NP levels with regard to urbanization or watershed size via qualitative comparison (Table 4 ).

\subsection{Sources of $N P$}

Bamfield, Canada, a remote town with a human population of about 250 in 2001, is near the northern range limit of the arrow goby. The organisms of this isolated area contain 4-NP, though at lipid-weight concentrations lower than other estuaries (Table 5). One common factor influencing all of these estuaries is the presence of household waste effluent, either through WWTP discharge, septic leach fields, or both. A ubiquitous element in these systems is toilet paper, which has been identified as a major input of NP to German wastewater (Gehring et al., 2004). All toilet paper analyzed contained measurable levels of 4-NP, with higher concentrations associated with higher content of recycled paper. While there are other inputs of NP to estuaries (e.g., household laundry and personal care products, industrial laundry waste water, and agricultural run off), the large volume of toilet paper that enters these systems may provide a sizable proportion of the contamination.

\section{Conclusion}

Our study revealed contamination in all western North American estuaries sampled and indicated toilet paper as one possible source of contamination, even in remote communities. 4-NP is present in all Morro Bay organisms tested, some at higher levels than worldwide estuarine species, with unknown consequences for many marine species and populations. We present evidence for an increase in 4-NP between species pairs in the local food chain, such as from goby to sculpin, and in the case of bivalves and sea otters, we see magnification to the level of the resident top predator. However, other marine mammals are not biomagnifying 4-NP, possibly due a combination of factors, such as a higher clearance rate and a weak link to the estuarine trophic chain.

\section{Acknowledgements}

Research was supported by the San Luis Obispo Science and Ecosystem Alliance (SLOSEA) funded by the David and Lucile Packard Foundation and the Resource Legacy Fund Foundation. Supplemental funding was provided by the Morro Bay National Estuary Program and the Regional Water Quality Control Board. Thank you to the organizations and individuals that provided samples: Bamfield Marine Science Center, Huu-ay-aht Nation, San Francisco Estuary Institute, Pacific Wildlife Care, Santa Barbara Museum of Natural History, Marine Mammal Center, CA Department of Fish and Game, Los Osos Community Services District, and City of San Luis Obispo Public Works. Thank you to the members of the Tomanek lab and their friends and family that helped to collect gobies in Morro Bay. Thanks to Megan Segal and Betsy Turner, both were integral to starting this Project. We are grateful to Dr. Sean Lema for editorial suggestions. 


\section{Appendix A. Supplementary material}

Supplementary data associated with this article can be found, in the online version, at doi:10.1016/j.chemosphere.2011.12.040.

\section{References}

Acevedo, R., Parnell, P.G., Villanueva, H., Chapman, L.M., Gimenez, T., Gray, S.L Balwin, W.S., 2005. The contribution of hepatic steroid metabolism to serum estradiol and estriol concentrations in nonylphenol treated MMTVneu mice and its potential effects on breast cancer incidence and latency. J. Appl. Toxicol. 25 339-353.

Chemical Market Reporter, 2001. Chemical Profile: Nonylphenol, Volume 260 Number 2. Schnell Publishing Company.

Correa-Reyes, G., Viana, M.T., Marquez-Rocha, F.J., Licea, A.F., Ponce, E., VazquezDuhalt, R., 2007. Nonylphenol algal bioaccumulation and its effect through the trophic chain. Chemosphere 68, 662-670.

Das, K.C., Xia, K., 2008. Transformation of 4-nonylphenol isomers during biosolids composting. Chemosphere 70, 761-768.

David, A., Fenet, H., Gomez, E., 2009. Alkylphenols in marine environments: distribution monitoring strategies and detection considerations. Mar. Pollut Bull. 58, 953-960.

EPA, 2006. National estuary program coastal condition report. United States Environmental Protection Agency, Office of Water, Washington DC, USA. EPA842/B-06/001.

Gatidou, G., Vassalou, E., Thomaidis, N.S., 2010. Bioconcentration of selected endocrine disrupting compounds in the Mediterranean mussel, Mytilus galloprovincialis. Mar. Pollut. Bull. 60, 2111-2116.

Gehring, M., Tennhardt, L., Vogel, D., Weltin, D., Bilitewski, B., 2004. Bisphenol A contamination of wastepaper, cellulose and recycled paper products. In Brebbia, C.A., Kungulos, S., Popov, V., Itoh, H. (Eds.), Waste Management and the Environment II: WIT Transactions on Ecology and the Environment, vol. 78. WIT Press, Southampton, Boston, MA, USA, pp. 294-300.

Han, X., Nabb, D.L., Mingoia, R.T., Yang, C., 2007. Determination of xenobiotic intrinsic clearance in freshly isolated hepatocytes from rainbow trout (Oncorhynchus mykiss) and rat and its application in bioaccumulation assessment. Environ. Sci. Technol. 41, 3269-3276.

Hu, J., Jin, F., Wan, Y., Yang, M., An, L., An, W., Tao, S., 2005. Trophodynamic behavior of 4-nonylphenol and nonylphenol polyethoxylate in a marine aquatic food web from Bohai Bay, North China: comparison to DDTs. Environ. Sci. Technol. 39 4801-4807.

Keller, H., Xia, K., Bhandari, A., 2003. Occurrence and transformation of estrogenic nonylphenol polyethoxylates and their metabolites in three northeast Kansas wastewater treatment plants. Pract. Period. Hazard. Toxic Radioact. Waste Manage. 7, 203-213.

Liber, K., Gangl, J.A., Corry, T.D., Heinis, L.J., Stay, F.S., 1999. Lethality and bioaccumulation of 4-nonylphenol in bluegill sunfish in littoral enclosures. Environ. Toxicol. Chem. 18, 394-400.

Mayer, T, Bennie, D., Rosa, F, Rekas, G, Palabrica, V, Schachtschneider, J, 2007. Occurrence of alkylphenolic substances in a Great Lakes coastal marsh, Cootes Paradise, ON. Canada. Environ. Pollut. 147, 683-690.

Post, D.M., 2002. Using stable isotopes to estimate trophic position: models, methods, and assumptions. Ecology 83, 703-718.

Post, D.M., Layman, C.A., Arrington, D.A., Takimoto, G., Quattrochi, J., Montaña, C.G., 2007. Getting to the fat of the matter: models, methods and assumptions for dealing with lipids in stable isotope analyses. Oecologia 152, 179-189.

Rempel, M.A., Schlenk, D., 2008. Effects of environmental estrogens and antiandrogens on endocrine function, gene regulation, and health in fish. In: Jeon, K.W. (Ed.), International Review of Cell and Molecular Biology, vol. 267. Elsevier Inc., New York, NY, USA, pp. 207-252.

Servos, M., 1999. Review of the aquatic toxicity, estrogenic responses and bioaccumulation of alkylphenols and alkylphenol polyethoxylates. Water Qual. Res. J. Can. 34, 123-177.

Soares, A., Guieysse, B., Jefferson, B., Cartmell, E., Lester, J.N., 2008. Nonylphenol in the environment: a critical review on occurrence, fate, toxicity and treatment in wastewaters. Environ. Int. 34, 1033-1049.

Soto, A.M., Justicia, H., Wray, J.W., Sonnenschein, C., 1991. P-Nonylphenol: an estrogenic xenobiotic released from "modified" polystyrene. Environ. Health Persp. 92, 167-173.

Staples, C., Mihaich, E., Carbone, J., Woodburn, K., Klecka, G., 2004. A weight of evidence analysis of the chronic ecotoxicity of nonylphenol ethoxylates, nonylphenol ether carboxylates, and nonylphenol. Hum. Ecol. Risk Assess. 10, 999-1017.

Vazquez-Duhalt, R., Marquez-Rocha, F., Ponce, E., Licea, A.F., Viana, M.T. 2005. Nonylphenol, an integrated vision of a pollutant. Appl. Ecol. Environ. Res. 4, 1-25.

Weisbrod, A.V., Woodburn, K.B., Koelmans, A.A., Parkerton, T.F., McElroy, A.E., Borgå, K. 2009. Evaluation of bioaccumulation using in vivo laboratory and field studies. Integr. Environ. Assess. Manage. 5, 598-623.

West, J.M., Williams, G.D., Madon, S.P., Zedler, J.B., 2003. Integrating spatial and temporal variability into the analysis of fish food web linkages in Tijuana Estuary. Environ. Biol. Fish. 67, 297-309.

Xia, K., Keller, H.L., Bhandari, A., Wagner, J., 2001. Occurrence, distribution, and fate of 4-nonylphenol in Kansas domestic wastewater treatment plants. J. Contemp. Water Res. Educ. 120, 41-48.

Ying, G., Williams, B., Kookana, R., 2002. Environmental fate of alkylphenols and alkylphenol ethoxylates - a review. Environ. Int. 28, 215-222.

Zar, J.H., 1996. Biostatistical Analysis, third ed. Prentice Hall, New Jersey, USA. 662 pp. 